\title{
Effect of Integrated Nutrient Management on Yield of Maize (Zea mays L.)
}

\author{
Dr.Ratan Lal Solanki ${ }^{1}$, Smt Deepa Indoriya ${ }^{2}$ \\ ${ }^{1}$ Soil Scientist, Krishi Vigyan Kendra (MPUAT, Udaipur), Chittorgarh, Rajasthan, India \\ ${ }^{2}$ T.A. Home Science, Krishi Vigyan Kendra (MPUAT, Udaipur), Chittorgarh, Rajasthan, India
}

\begin{abstract}
The basic concept underlying the principles of integrated nutrient management (INM) is the maintenance and improvement of soil fertility for sustaining crop productivity (both quantity and quality wise). The study was carried out during Kharif season of 2013-14 and 2014-15 in two villages across two blocks (Nibaheda and Gangrar) of Chittorgarh district of Rajasthan. In all 30 integrated nutrient management front line demonstrations on maize crop were carried out in an area of 6.0 ha with the active participation of farmers with the objective to demonstrate the latest technology of maize production potential, technological and extension gap, technology index and economic benefit of improved technologies consisting suitable maize varieties Bio 9681 and Prable integrated nutrient management (90:30:30:25 NPK \& ZnSO4 kg ha $\mathrm{kg}^{-1}+$ Azotobacter + PSB @ 20 $\mathrm{gkg}^{-1}$ seed) + seed treatment with Trichoderma viride @ $5 \mathrm{gkg}^{-1}$ seed) at Nibaheda and Gangrar blocks of Chittorgarh district during 2013-14 and 2014-15. The results revealed that INM FLD recorded higher yield as compared to farmers' practices over the years of study. The improved technologies recorded average yield of $43.71 \mathrm{q} \mathrm{ha}^{-1}$ which was 24.20 per cent higher than that obtained with farmer's practices of $35.18 \mathrm{q} \mathrm{ha}$.1. In spite of increase in yield of maize, technological gap, extension gap and technology index existed which was 6.29, $8.53 \mathrm{q} \mathrm{ha}^{-1}$ and $12.58 \mathrm{per}$ cent, respectively. The extension gap can be bridged by popularizing package of practices where in stress need to be laid on improved variety, use of proper seed rate, balanced nutrient application and proper plant protection measures. Improved technologies gave higher net return of Rs. 31221 ha $^{-1}$ with benefit cost ratio 2.47 as compared to local check (Rs. $22886 \mathrm{ha}^{-1}$, benefit cost ratio 2.19).
\end{abstract}

Keywords-Maize, INM-FLD, Extension gap, Technological gap, Technology index, Yield, Economics.

\section{INTRODUCTION}

Maize (Zea mays L.) is the most important cereal crop and known as queen of cereal due to unparallel productivity among cereal crops. In India, maize occupies third position both in area and production after rice and wheat. In Rajasthan it is grown on 1.0 million ha area with production $1.21 \mathrm{~m}$ tons and productivity of $1374 \mathrm{~kg} \mathrm{ha}^{-1}$. Agriculture is the main stay of life in district Chittorgarh of Rajasthan with a average gross cropped area of 118320 ha. The district has a Sub Humid Southern Plains humid climate with average temperature of the district varies from $30--45^{\circ} \mathrm{C}$ in summer and $5-25^{\circ} \mathrm{C}$ in winter. The annual rainfall of the district is about $772 \mathrm{~mm}$. Maize is one of the important cereal crops grown in kharif season in the district. Chittorgarh covers 123933 ha of land under maize cultivation with average productivity of $2253 \mathrm{~kg} \mathrm{ha}^{-1}$ (Anonymous. 2014) is far below average national productivity $\left(2435 \mathrm{~kg} \mathrm{ha}^{-1}\right)$. The potential expected from improved technologies due to erratic rainfall, small land holdings, and adoption of local cultivar, low and imbalance use of fertilizer and no use of plant protection measures. Yield of maize can be enhanced at least $24.20 \%$ with adoption of improved technologies such as improved cultivar, recommended dose of fertilizer and control of pests (Dhaka et al. 2010), fertilizer and plant protection are most critical inputs for increasing yield (Mishra et al. 2009). Realizing the situation INM front line demonstrations on maize production technology were planned and conducted to show the production potential, economic benefit of improved technologies under real farmers' conditions.

\section{MATERIALS AND METHODS}

In the present study performance of improved technologies of maize against local check was evaluated through INM front line demonstrations conducted at farmer's field during Kharif season of 2013-14 and 2014-15. A total of 30 demonstrations were laid on 6.0 hectare area in 02 villages across two blocks (Nibaheda and Gangrar) of Chittorgarh district of Rajasthan. In the year 2013, front line demonstrations conducted in 03 ha area on maize with variety Bio-9681and the year 2014 variety of Prable (Maize) has sown. The each demonstration of improved technologies of maize was demonstrated in an area of 0.2 
to 0.4 ha adjacent to the plots of farmer's practices (Local check). Soils of the study area are mostly sandy clay loam in texture with low nitrogen, medium phosphorus and available potassium. The improved technologies included improved varieties (cv. Bio-9681 during 2013 and cv. 'Prable' during 2014), integrated nutrient management (90:30:30:25 NPK \& $\mathrm{ZnSO}_{4} \mathrm{~kg} \mathrm{ha}^{-1}+$ PSB @ $20 \mathrm{gkg}^{-1}$ seed) + seed treatment with Trichoderma viridae @ $6 \mathrm{gkg}^{-1}$ seed) were tested under demonstrations. Deep ploughing was done during the month of April. Crop was sown after receiving sufficient rainfall, between last week of June to $2^{\text {nd }}$ week of July with crop geometry of $60 \times 20 \mathrm{~cm}$ and seed sown at $25 \mathrm{~kg} \mathrm{ha}^{-1}$. Total amount of phosphorus, potassium and zinc sulphate applied through DAP , MOP and $\mathrm{ZnSO}_{4}$ as basal dose and nitrogen through urea as top dressed in two equal splits at 30 and 45 days after sowing. The seeds were treated with Trichoderma viridae @ $6 \mathrm{gkg}^{-1}$ seed and then seeds were inoculated by Azotobacter and phosphor-solubilizing bacteria biofertilizers each $20 \mathrm{gkg}^{-1}$ seeds. Hand weeding was done once at 25 days after sowing. The crop was harvested between second weeks of October. At harvesting, five random samples of one meter square area from each demonstration fields were harvested and composite sample was weighted for total biological yield. After weighing, seeds were separated by beating and cleaned grains were weighted for grain yield. The technology gap, extension gap and technology index were calculated as suggested by Samui et al. (2000).

Table.1: Productivity, technology gap, extension gap and technology index of maize under INM FLDs

\begin{tabular}{|c|c|c|c|c|c|c|c|c|c|}
\hline \multirow[t]{2}{*}{ Year } & \multirow{2}{*}{$\begin{array}{r}\text { Area } \\
\text { (ha) }\end{array}$} & \multirow{2}{*}{$\begin{array}{l}\text { No. of } \\
\text { farmers }\end{array}$} & \multirow[t]{2}{*}{ Potential } & \multicolumn{2}{|c|}{ Yield $\left(\mathrm{qha}^{-1}\right)$} & \multirow{2}{*}{$\begin{array}{l}\text { Per cent increase } \\
\text { In yield over local } \\
\text { check }\end{array}$} & \multirow{2}{*}{$\begin{array}{l}\text { Technolog } \\
\text { y } \\
\text { Extension } \\
\text { gap }\left(\mathrm{qha}^{-1}\right)\end{array}$} & \multirow{2}{*}{$\begin{array}{l}\text { Techno } \\
\text { logy } \\
\text { gap } \\
\left(\mathrm{qha}^{-1}\right)\end{array}$} & \multirow{2}{*}{$\begin{array}{l}\text { Technolog } \\
y \\
\text { Index }(\%)\end{array}$} \\
\hline & & & & Improved & Local & & & & \\
\hline 2013 & 3.0 & 15 & 50.0 & 41.78 & 33.97 & 22.99 & 8.22 & 7.81 & 16.44 \\
\hline 2014 & 3.0 & 15 & 50.0 & 45.64 & 36.39 & 25.42 & 4.36 & 9.25 & 8.72 \\
\hline Mean & 3.0 & 15 & 50.0 & 43.71 & 35.18 & 24.20 & 6.29 & 8.53 & 12.58 \\
\hline
\end{tabular}

Table.2: Cost of cultivation $\left(\right.$ Rsh $\left.^{-1}\right)$, net return $\left(\right.$ Rsh $\left.^{-1}\right)$ and B: C ratio as affected by improved technology and local practices

\begin{tabular}{|c|c|c|c|c|c|c|}
\hline \multirow[t]{2}{*}{ Year } & \multicolumn{2}{|c|}{ Cost of cultivation } & \multicolumn{2}{|c|}{ Net Returns } & \multicolumn{2}{|c|}{ B:C Ratio } \\
\hline & Improved & Lock check & Improved & Lock check & Improved & Lock check \\
\hline 2013 & 20210 & 18210 & 29926 & 22254 & 2.48 & 2.22 \\
\hline 2014 & 22252 & 20150 & 32516 & 23518 & 2.46 & 2.16 \\
\hline Mean & 21231 & 19180 & 31221 & 22886 & 2.47 & 2.19 \\
\hline
\end{tabular}

The technological gap, which is the difference between potential and demonstration yield was maximum in the year $2013\left(8.22 \mathrm{qha}^{-1}\right)$ and lowest in the year $2014(4.36$ qha-1). However, overall average technological gap in the study was $6.29 \mathrm{qha}^{-1}$. The technological gap observed may be attributed to the dissimilarity in soil fertility status and
Technology Gap = Potential yield - Demonstration yield

Extension Gap $=$ Demonstration yield - Farmers yield

Technology Index $(\%)=$

$\frac{\text { Potential yield-demonstration yield }}{\text { Potential yield }} \times 100$

III. RESULTS AND DISCUSSION

Perusal of data indicated that the average yield of maize was substantially higher as compared to local check over the years of study (Table 1). The productivity of maize ranged from 41.78 to $45.64 \mathrm{qha}^{-1}$ with mean yield 43.71 $\mathrm{qha}^{-1}$ under improved technologies at farmers fields as against a yield ranged from 33.97 to 36.39 qha $^{-1}$ with an average of 35.18 qha $^{-1}$ under farmer's practices (local check). The highest productivity following improved technology was during the year 2014 which is might be due to improved cultivar Prable and rainfall received on the critical stages of crop growth. Increase in yield was 22.99 and 25.42 percent higher as compared to local check, during 2013 and 2014, respectively. The higher yield of maize under improved technologies was due to the latest high yielding varieties, integrated nutrient management and integrated pest management. Similar results have been reported earlier by Segar and Chandra (2004), Jeengar et al. (2006) and Dhaka et al. (2010). weather conditions. Mukharjee (2003) has also opined that depending on identification and use of farming situation, specific interventions may have greater implications in enhancing system productivity. The extension gap ranged from 7.81 to $9.25 \mathrm{qha}^{-1}$ during the period of study emphasizes the need to educate the farmers through various 
means for adoption of improved technologies to reverse the trend of wide extension gap. Technology index shows the feasibility of evolved technology at the farmer's field and lower the value of technology index more is the feasibility of the technology (Jeengar et al. 2006). Technology index in the present case varied between 8.72 to 16.44 per cent and averaged 12.58 per cent during the period of study.

The inputs and outputs prices of commodities prevailed during each year of demonstrations were taken for calculating cost of cultivation, net return and benefit cost ratio (Table 2). The investment on production by adopting improved technologies ranged from Rs. 29926 to 32516 ha ${ }^{1}$ with a mean value of Rs. 31221 ha $^{-1}$ against local check where the variation in cost of production ranged from Rs. 20210 to $22252 \mathrm{ha}^{-1}$ with an average of Rs. $21231 \mathrm{ha}^{-1}$. The cultivation of maize under improved technologies gave higher net return of Rs. 29926 and $32516 \mathrm{ha}^{-1}$ as compared to Rs. 22254 and 23518 ha $^{-1}$ under local check in the corresponding years. The average benefit cost ratio of improved technologies was 2.47 , varying from 2.46 to 2.48 and that of local check was 2.19 , varying from 2.16 to 2.22 . This may be due to higher yields obtained under improved technologies compared to local check (farmers practice). This finding is in corroboration with the finding of Mokidue et al. (2011), Tomar (2010) and Solanki et al. (2014).

\section{Reasons of low yield of maize at farmer's fields}

Optimum sowing time is not followed due delay in monsoon. Sometimes non availability of quality seed or variety seed and farmers go for the local seed in hand. More than 80 per cent of farmers maize seed sowing in closer spacing and in most of the situation the plant population at farmer's field is high or two-three times high of the recommended stand. Lack of popularization of seed cum fertilizer drill for sowing and use of inadequate and imbalance dose of fertilizers especially the phosphatic, potesic fertilizers by farmers does not make possible to fetch potential yield. The problem of nutrient deficiency in maize plant substantial loss in the maize crop yield measures. Mechanical weed control is costly and chemical control is quite uncommon in this region.

Specific constraints with marginal/sub marginal farmer's Small holding: The adoption of well proven technology is constrained due to small size of holding and poor farm resources. Small and marginal farmers have less capability to take risk and do not dare to invest in the costly inputs due to high risk and the poor purchase capacity of small farmer.
Farm implements and tools: Traditional implements and tools are still in practice due to small holdings which have poor working efficiency. The lack of simple modern tools for small holdings also hinders the adoption of improved technologies.

\section{CONCLUSION}

Thus, the cultivation of maize with improved technologies including suitable variety with integrated nutrient has been found more productive and grain yield might be increase up to $25.42 \%$. Technological and extension gaps existed which can be bridged by popularizing package of practices with emphasis on improved variety seed, use of proper seed rate, balanced nutrient application-integrated nutrient management. Replacement of local variety with the released variety of maize would increase the production and net income by more than nine thousand rupees.

\section{REFERENCES}

[1] Anonymous. 2014. Agricultural Statistics at a Glance. Directorate of Economics \& Statistics, Department of Agriculture \& Cooperation, New Delhi.

[2] Dhaka B L, Meena B S and Suwalka R L. 2010. Popularization of Improved Maize Production Technology through Frontline Demonstrations in South-eastern Rajasthan. Journal of Agricultural Sciences 1(1): 39-42.

[3] Jeengar K L, Panwar P and Pareek O P. 2006. Front line demonstration on maize in bhilwara District of Rajasthan. Current Agriculture 30(1/2): 115-116.

[4] Katare Subhash, Pandey, SK, \& Mustafa Mohd. (2011). Yield gap analysis of Rapeseed- Mustard through front line demonstrations. Agric update 6: 57.

[5] Mishra D K, Paliwal D K, Tailor R S and Deshwal A K. 2009. Impact of frontline demonstrations on yield enhancement of potato. Indian Research Journal of Extension Education 9(3): 26-28.

[6] Mokidue I, Mohanty A K and Sanjay K. 2011. Correlating growth, yield and adoption of urdbean technologies. Indian Journal of Extension Education 11(2): 20-24.

[7] Mukharjee N. 2003. Participatory learning and action. Concept Publishing Company, New Delhi. pp 63-65.

[8] Sagar RL, Ganesh Chandra (2004). Front line demonstration on sesame in West Bengal. Agric Ext Rev 16: 7-10.

[9] Samui S K, Maitra S, Roy D K, Mondal A K and Sahu D. 2000. Evaluation of front line demonstration 
on groundnut. Journal of Indian Society of Costal Agricultural Research 18(2): 180-306.

[10] Solanki, R.L., Rathore, R.S., Dhakar, S.D. and Kanojia, Y. 2014. Yield gap analysis of integrated nutrient management in maize through front line demonstration. International Journal of plant science. Volume 9 | Issue2 | 438-440

[11] Tomar LS, Sharma PB, Joshi, K. (2003). Study on yield gap and adoption level of potato Production technology in grid region. Maharashtra J Ext Educ 22 : $15-18$

[12] Tomar R K S. 2010. Maximization of productivity for chickpea (Cicer arietinum Linn.) through improved technologies in farmer's fields. Indian Journal of National Products and Resources 1(4): 515-517. 